\title{
Perancangan Sistem Informasi Penjualan Serta Perbaikan Komputer (Studi Kasus TNG Computer)
}

\author{
Sales Information System Design and Computer Repair (Case Study : TNG Computer)
}

\author{
Fetty Ade Putri \\ Universitas Potensi Utama \\ J1. KL. Yos Sudarso Km. 6,5 No. 3A, Tanjung Mulia, Medan \\ E-mail: echiputri12@gmail.com
}

\begin{abstract}
Abstrak
Teknologi menjadi salah satu elemen penting dan dapat merubah alur yang tadinya rumit serta lambat menjadi lebih efisien juga efektif. Salah satunya yang berubah adalah sistem informasi pengolahan data pada perusahaan. TNG Computer adalah salah satu perusahaan yang bergerak di bidang bisnis teknologi, namun dalam penyusunan data, baik penjualan maupun perbaikan komputer, masih secara manual dengan menggunakan kuitansi yang kemudian disimpan ke dalam Microsoft Excel sehingga kurang efektif dan efisien. Tujuan dari penelitian ini adalah untuk membantu TNG Computer dalam merancang suatu sistem informasi baik penjualan mauapun perbaikan komputer yang terkomputerisasi dan disimpan dalam satu database sehingga dapat mempermudah karyawan dalam memasukan data pelanggan serta membuat laporan yang dibutuhkan dan dapat menghemat waktu serta kertas dalam prosesnya.
\end{abstract}

Kata Kunci-Sistem Informasi, Sistem Informasi Penjuaalan, Penjualan.

\begin{abstract}
Technology is one of the important elements and can change the flow that was previously complicated and slow to become more efficient and effective. One thing that has changed is the company's data processing information system. TNG Computer is one of the companies engaged in the technology business, but in compiling data, both sales and computer repair, it is still manually using receipts which are then stored in Microsoft Excel so that it is less effective and efficient. The purpose of this study is to assist TNG Computer in designing an information system for both sales and computer repair that is computerized and stored in one database so that it can make it easier for employees to enter customer data and make reports needed and can save time and paper in the process.
\end{abstract}

Keywords - Information System, Sales Information System, System.

\section{PENDAHULUAN}

Di masa sekarang ini, teknologi menjadi elemen yang sangat dibutuhkan dalam kehidupan manusia. Teknologi dapat membantu menyelesaikan permasalahan yang dialamai oleh tiap-tiap bagian masyarakat, mulai dari bagian yang terkecil seperti pasar hingga ke tingkatan yang lebih tinggi seperti pendidikan, perusahaan, pemerintahan, dan lain sebagianya.

Pada tingkatan perusahaan, salah satu yang berubah adalah adanya sistem informasi pengolahan data. Dengan adanya sistem informasi pengolahan data, perusahaan-perusahaan, baik kecil, menengah maupun besar dapat dengan mudah dan cepat mengakses informasi yang 
dibutuhkan karena telah disimpan dalam suatu base data (database). Data yang tadinya masih disusun secara manual dan rawan terjadi kerusakan kini dapat dengan mudah disimpan, diolah, dan ditampilkan dengan adanya sistem ini.

Sistem informasi pengolahan data tersebut juga diharapkan dapat menyajikan informasiinformasi yang dibutuhkan oleh perusahaan-perusahaan secara cepat dan tepat. Informasi yang dihasilkan oleh sistem tersebut nantinya diharapkan dapat membantu serta memenuhi kebutuhan dalam mobilisasi maupun pengambilan keputusan oleh perusahaan.

Salah satunya adalah TNG (Technology Next Generation) Computer yang merupakan sebuah perusahaan yang beroperasi dalam bidang penjualan serta perbaikan komputer. Namun, dalam prosesnya, perusahaan ini terbilang cukup lambat. Hal ini dikarenakan aktifitas yang berkaitan dengan proses pengolahan informasi yang masih dikerjakan secara konvensional. Salah satunya adalah dalam mengolah data informasi proses transaksi jual beli dan perbaikan komputer di mana admin masih menggunakan cara pencatatan tertulis di dalam buku dan faktur yang kemudian akan disimpan ke dalam file Ms. Excel. Tentu saja hal ini dapat mempersulit admin dalam mencari data pelanggan, baik yang sudah maupun yang belum pernah melakukan transaksi.

Begitu juga dalam pencatatan inventoris, seperti stok barang, hingga ketersediaan komponen yang dimiliki, masih dilakukan secara manual. Hal ini juga mengakibatan admin maupun karyawan kesulitan dalam melakukan penyusunan serta pelaporan seperti penjualan barang serta komponen apa saja yang dipakai dalam perbaikan komputer yang dilakukan.

Beberapa penelitian terdahulu yang peneliti gunakan sebagai bahan referensi peneliti, yaitu Penelitian yang dilakukan oleh Puspita Dwi Astuti[1] yang membahas tentang sistem informasi penjualan obat berbasi desktop. Penelitian ini menyajikan sebuah aplikasi yang dibangun dengan menggunakan software Visual basic. Adapun tujuan dari dibangunnya sistem adalah untuk meringankan tugas asisten apoteker dan membuat kinerja apotek menjadi lebih efektif dan efisien.

Lalu Penelitian yang dilakukan oleh Sutri Handayani[2] yang membahas tentang perancangan sistem informasi penjualan berbasis e-commerce. Hasil dan kesimpulan dari penelitian ini adalah website penjualan berbasis ecommerce dapat dijadikan sebagai media promosi, mempermudah proses penjualan yang dilakukan secara online, serta dapat mempermudah dalam pengolahan data dan pencetakan laporan yang tidak lagi memerlukan pencatatan dalam bentuk arsip.

Penelitian oleh Agus Irawan, dkk[3] yang dengan perancangan sistem informasi penjualan pakaian berbasis online di mana perancangan sistem dibuat melalui tahapan Context Diagram, Flowmap, Data Flow Diagram, Normalisasi tabel, ERD, struktur database, desain input dan output serta struktur menu program, dengan mengahsilkan 7 buah form atau tabel database yang saling berhubungan dalam membangun sistem. Hasilnya adalah sebuah aplikasi sistem penjualan online dengan tampilan interface yang user friendly serta mudah dipelajari oleh operator, owner dan juga pelanggan.

Ada pula penelitian yang dilakukan oleh Ade Pebrianto[4] dengan pembahasan berupa rancangan aplikasi penjualan donat pada perusahaan King Alianz Donuts sebagai bentuk upaya pengembangan dalam hal pelayanan. Hasil dari penelitian ini adalah sebuah aplikasi yang dapat membantu memenuhi kebutuhan perusahaan dalam proses penyimpanan data-data pesanan pada perusahaan King Alianz Donuts. Selain itu, pengendalian stok donat dan varian rasa yang ada di pabrik bisa diatasi, karena segala bentuk proses transaksi dihubungkan dengan database yang saling terintegrasi, selain itu pembuatan laporan menjadi lebih mudah, dan dapat membantu untuk memperbaiki kesalahan pada penulisan data.

Selanjutnya ada penelitian yang dilakukan oleh Angling Ananditya[5] perancangan sistem informasi penjualan voucher game online berbasis desktop. Penelitian ini dilakukan dengan tujuan untuk membuat sebuah sistem berbasis desktop yang efisien dan dapat membantu kinerja warnet pada saat transaksi. Hasilnya adalah sebuah sistem dengan tampilan interface sederhana yang dapat mempermudah proses transaksi penjualan voucher menjadi lebih efektif, karena di 
sistem ini sudah otomatis tersedia data voucher dan stok voucher. Proses transaksi juga sudah terkomputerisasi, sehingga dapat mempermudah dan mempercepat waktu pekerjaan dalam pengolahan data penjualan voucher.

Ada pula penelitian yang dilakukan oleh Isabel Ananda dan Eva Zuraidah[6] yang membahas tentang perancangan sistem informasi penjualan barang berupa suku cadang atau spare part pada PT Asia Truck Pratama di Jakarta. Perancangan sistem menggunakan metode pendekatan sistem berorientasi objek dan Waterfall model sebagai metode pengembangan sistemnya. Hasil yang didapat adalah sebuah sistem yang dapat mempermudah dalam proses jual-beli, pembuatan laporan dan pencarian data penjualan karena sistem yang saling terintegrasi. Sistem yang dirancang juga dapat mengurangi kesalahan dalam peng-input-an dibandingkan sistem yang sebelumnya serta dengan keamanan data yang lebih baik pula.

Selanjutnya ada penelitian oleh Dimas Aji Saputro dan Silvi[7] tentang perancangan sistem informasi penjualan ban truk di mana sebelumnya segala hal yang berkaitan dengan proses penjualan, pencatatan customer yang membeli barang, sampai penyimpanan data-data lainnya yang berhubungan hingga sampai pembuatan laporan masih dilakukan secara manual sehingga memungkinkan pada saat proses berlangsung terjadi kesalahan dalam pencatatan, kurang akuratnya laporan yang dibuat dan keterlambatan dalam pencarian data-data yang diperlukan. Penelitian ini menghasilkan sebuah sistem penjualan yang dapat mempermudah proses jual beli yang awalnya customer harus datang ke workshop langsung untuk membeli barang, kini customer dapat memesan barang dari manapun. Selain itu, pembuatan laporan penjualan \& stok barang, data penjualan yang tersimpan di sistem akan menjadi lebih aman dan efisien, mempermudah customer dalam penerimaan barang, yaitu barang akan di antar oleh jasa expedisi.

Selanjutnya ada penelitian yang dilakukan oleh Hermanda Ihut Tua Simamora[8] yang membahas tentang perancangan sistem informasi penjualan bahan-bahan kebutuhan masyarakat sehari-hari pada sebuah mini market dengan menggunakan prototipe. Sama seperti penelitianpenelitian yang telah dipaparkan sebelumnya, proses jual-beli masih dilakukan secara manual. Hasil dari penelitian ini adalah sebuah sistem informasi penjualan berbasis web dengan fitur-fitur yang akan dibangun adalah data penjualan, inventaris barang, informasi harga, dan cetak faktur dengan pengembangan sistem menggunakan metode prototype dan bahasa pemograman PHP. Sistem informasi penjualan ini diharapkan dapat meningkatkan efektitivitas dan efesiensi cara kerja proses bisnis, seperti kemudahan dalam mengetahui harga, kemudahan menghasilkan laporan penjualan, inventasi dan kemudahan dalam mencetak faktur.

Lalu ada penelitian oleh Achmad Sidik, dkk [9] dengan pembahasna tentang sistem informasi penjualan rumah pada suatu komplek perumahan. Penelitian ini menyajikan sebuah aplikasi yang dibangun dengan metode perancangan berbasi object oriented and design dan menggunakan Unified Modelling Language (UML). Hasil yang didapat dari analisa dan perancangan sistem penjualan ini sistem penjualan ini dapat membantu mempermudah proses pendataan serta dapat memenuhi kebutuhan informasi yang selama ini sulit untuk dipenuhi, seperti pendataan customer yang melakukan pembelian, pendataan listing rumah, dan pendataan marketing. Sistem tersebut juga dapat menghasilkan laporan-laporan yang dibutuhkan seperti laporan data pembelian rumah, laporan data listing rumah marketing, yang menjadi hambatan saat masih menggunakan metode manual.

Terakhir ada penelitian oleh Aad Aediyansyah[10] dengan pembahasan berupa sistem informasi penjualan daur ulang botol bekas berbasis web. Tujuan dari penelitian ini adalah untuk mempermudah konsumen dalam pembelian produk secara online tanpa harus datang langsung ke pabrik. Selain itu sistem ini juga memudahkan konsumen untuk mendapatkan informasi tentang produk secara detail melalui website. Hasil yang didapat adalah sebuah sistem informasi pengelolaan pendataan botol-botol bekas untuk daur ulang yang dapat memberikan kemudahan informasi pada konsumen juga pemilik usaha. Sistem ini dapat menyediakan informasi sesuai yang dibutuhkan pengelola daur ulang botol bekas, seperti laporan transaksi pemesanan botol daur ulang serta laporan penjualan. 
Dengan adanya kasus-kasus yang telah disebutkan, maka dibutuhkanlah sebuah sistem informasi pengolahan data yang dapat mempermudah serta mempercepat proses mulai dari pencatatan, penyusunan, hingga membuat laporan data yang dibutuhkan oleh perusahaan.

\section{METODOLOGI PENELITIAN}

Bagian ini akan menguraikan tentang metodologi penelitian yang digunakan dalam menyelesaikan permasalah yang ada pada penelitian ini. Metodologi penelitian dimanfaatkan dalam membantu peneliti dalam aktivitas kerja penyelesaian masalah. Metodologi penelitian ini dilakukan secara sistematis dan digunakan sebagai acuan dalam penelitian. lain:

Dalam pelaksanaan penelitian ini, penulis menggunakan beberapa metode penelitian antara

\section{a. Pengamatan (Observation)}

Observasi adalah melakukan pengamatan langsung ke tempat penelitian, lalu mengamati dan mengumpulkan data-data yang sesuai dengan judul yang dangkat. Di sini penulis ditempatkan pada bagian staf perusahaan.

\section{b. Wawancara (Interview)}

Dalam hal ini, penulis memperoleh informasi yang dibutuhkan dengan bertanya langsung kepada pihak-pihak yang berkaitan dalam perusahaan tersebut, untuk mendapatkan informasi mengenai pengelolaan data-data seputar penjualan yang juga mencakup data pelanggan serta stok dalam inventori perusahaan. Penulis juga melakukan Tanya jawab kepada Ibu Dewi Purnama selaku HRD Dalam perusahaan tersebut. Topik dari wawancara tersebut adalah:

1. Bagaimana proses pengelolaan data yang masih menggunakan sistem manual berupa tulis tangan dan Microsoft office excel.

2. Permasalahan apa yang sering terjadi dalam proses pengelolaan data kostumer dan stok barang.

3. Permasalahan apa yang sering terjadi dalam proses pencarian data baik data kostumer ataupun data stok barang yang akan dijual.

\section{c. Sampel (Sampling)}

Dalam hal ini penelitian berdasarkan keputusan dengan mengumpulkan data perusahaan seputar penjualan dan reperasi di Tahun 2017 dan untuk jumlah sampel penulis menggunakan beberapa contoh data penjualan di TNG Computer.

\section{d. Penelitian Kepustakaan (Library Research)}

Suatu Metode Penelitian berdasarkan keputusan dengan mengumpulkan data, keterangan atau informasi dimana penulis berpedoman dengan buku-buku dan pustaka lainnya yang berkaitan dengan penelitian

\subsection{Kerangka Kerja Penelitian}

Adapun tahapan-tahapan dalam kerangka kerja penelitian yang digunakan dalam penelitian ini dapat dilihat pada gambar berikut. 


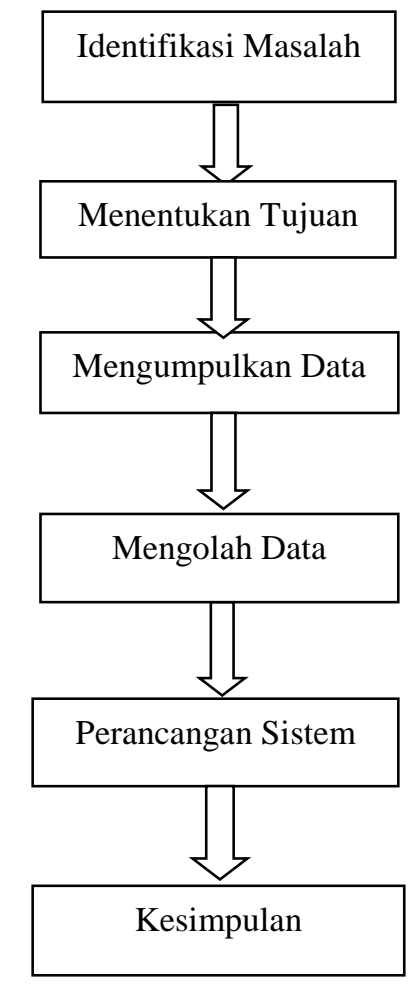

Gambar 1: Kerangka Kerja Penelitian

Keterangan:

1. Identifikasi Masalah: Mengidentifikasi serta menganalisa permasalahan yang ada diharapkan dapat secara jelas memaparkan bagaimana cara mengatasi masalah tersebut dengan baik. Dalam menganalisa dan mengidentifikasi masalah diperlukannya data-data yang berhubungan dengan masalah serta berkaitan dengan penelitian.

2. Menentukan Tujuan: Tujuan yang akan dicapai dalam penelitian ini ditentukan berdasarkan pemahaman dari masalah.

3. Mengumpulkan Data: Setelah masalah telah teridentifikasi dan tujuan telah ditetapkan, maka tahap yang dilakukan selanjutnya adalah menumpulkan data. Data-data yang telah dikumpulkan tersebut lalu dikelompokkan berdasarkan pengelompokan yang telah ditentukan. Dalam memperoleh data bisa dilakukan dengan beberapa cara, seperti dengan wawancara

4. Mengolah Data: Setelah semua data telah terkumpul dan dikelompokan, hal selanjutnya dilakukan adalah mengolah data yang ada

5. Perancangan Sistem: Setelah data telah diolah maka dibuatlah sebuah perancangan sistem yang sesuai dengan kebutuhan dan data yang telah diolah sebelumnya. Pada perancangan sistem ini juga dibuat desain interface yang menarik dan user friendly dari sistem yang akan dibangun agar tampilan dari sistem tidak membosankan.

6. Kesimpulan: Setelah semua langkah-langkah telah terpenuhi, maka hal selanjutnya yang dilakukan adalah membuat laporan dan menarik kesimpulan dari keseluruhan penelitian. 


\section{HASIL DAN PEMBAHASAN}

\subsection{Use Case Diagram}

Use case diagram merupakan sebuah skema yang memvisualisasikan kumpulan use case dan aktor-aktor yang merupakan salah satu jenis khusus dari kelas (class). Diagram use case memiliki dua peranan, yaitu: (1) menjelaskan fitur-fitur yang harus disuguhkan oleh sistem dan (2) menerangkan sifat sistem dari sudut pandang user[11].

Gambaran model use case pengolahan data pelanggan penjualan dan perbaikan komputer di TNG Computer dapat dilihat pada gambar berikut.

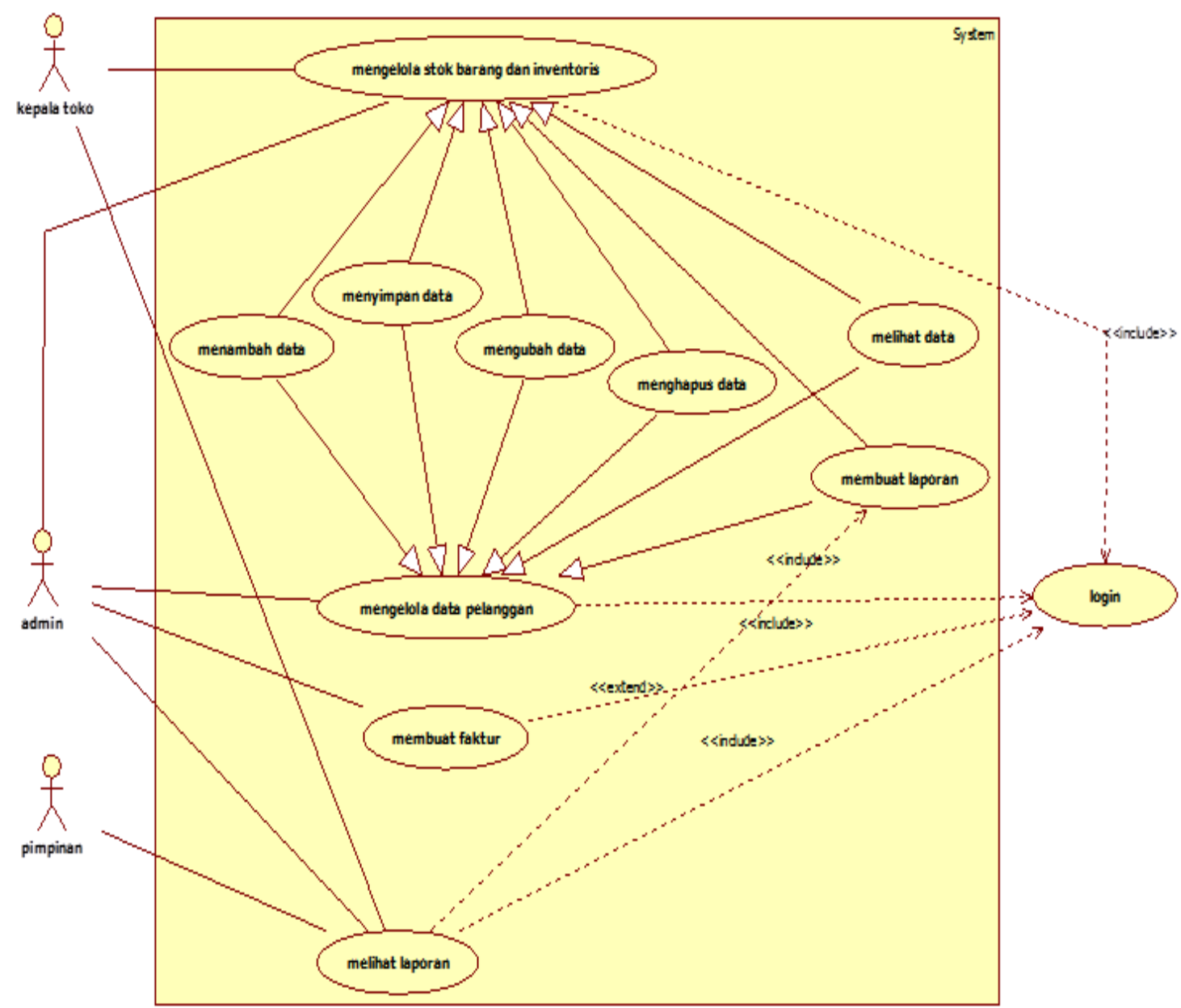

Gambar 2: Use Case Diagram Pengolahan Data Pelanggan Penjualan Dan Perbaikan Gadget TNG Computer

\subsection{Class Diagram}

Class Diagram atau diagram kelas adalah visualisasi susunan sistem dari segi penggambaran kelas-kelas yang digunakan dalam membangun sistem. Diagram kelas mempunyai atribut atau komponen-komponen yang dimiliki oleh sebuah kelas dan juga metode atau operasi yang merupakan kegunaan yang dimiliki oleh sebuah kelas[12]. 
Class Diagram dibangun dengan tujuan pembuat program (developer) mampu membuat kelas-kelas yang sesuai dengan rancangan dalam diagram, sehingga adanya sinkronisasi antara dokumen dengan perancangan perangkat lunak (software).

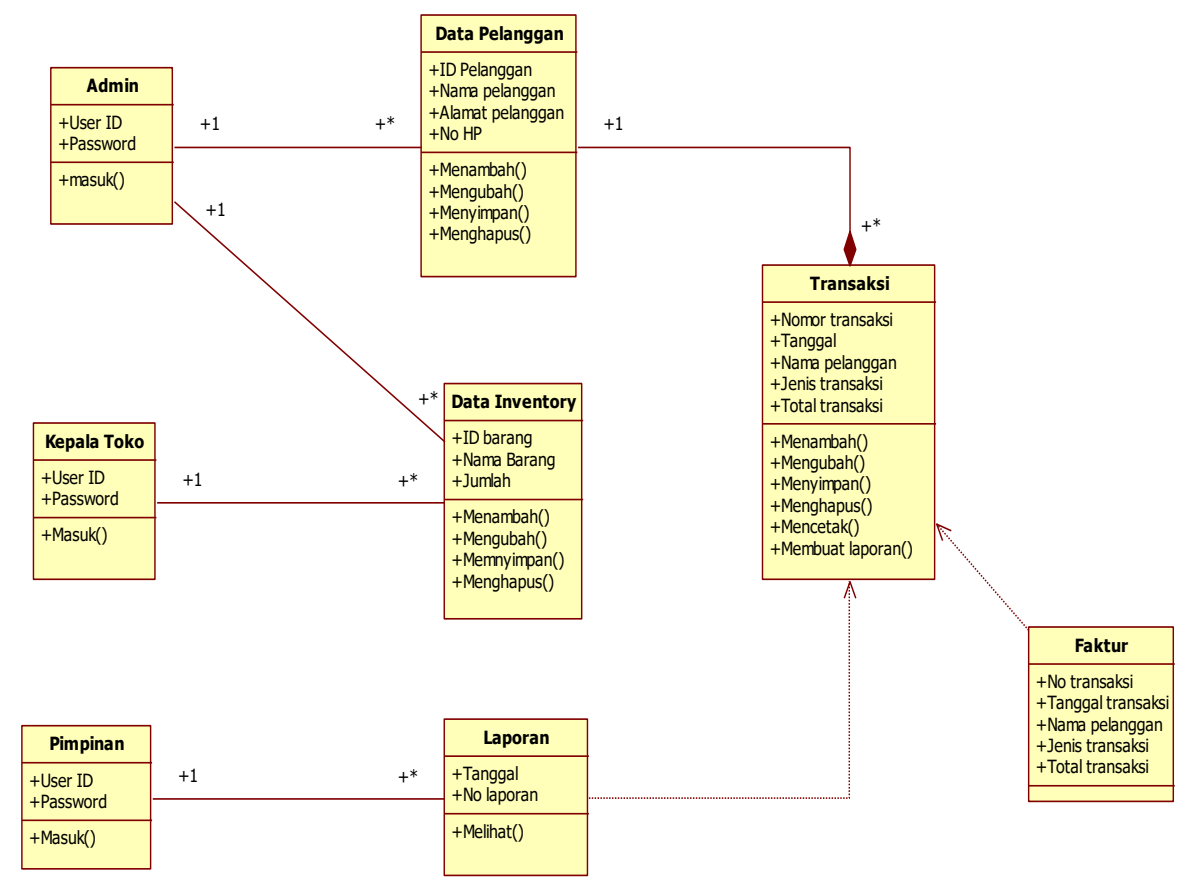

Gambar 3: Class Diagram Pengolahan Data Pelanggan Penjualan Dan Perbaikan Gadget TNG Computer

\subsection{Tampilan Interface}

Berikut merupakan hasil dari tampilan sistem yang telah dirancang sesuai dengan Use Case.

a) Halaman Login

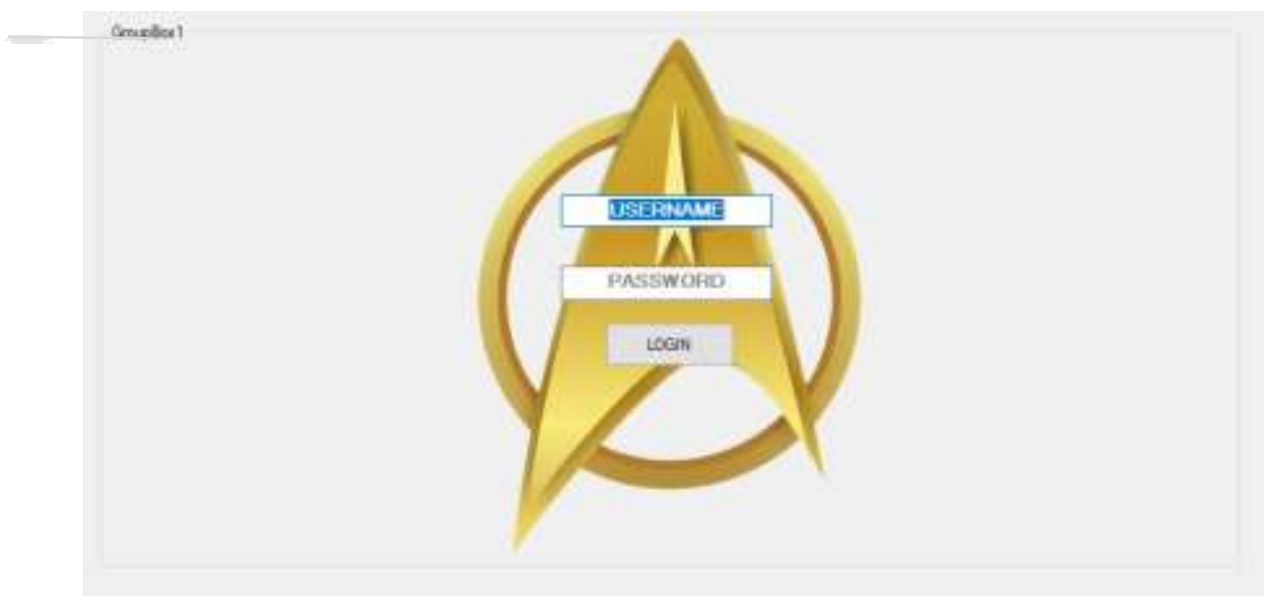

Gambar 4: Tampilan Halam Login 
b) Halaman Admin

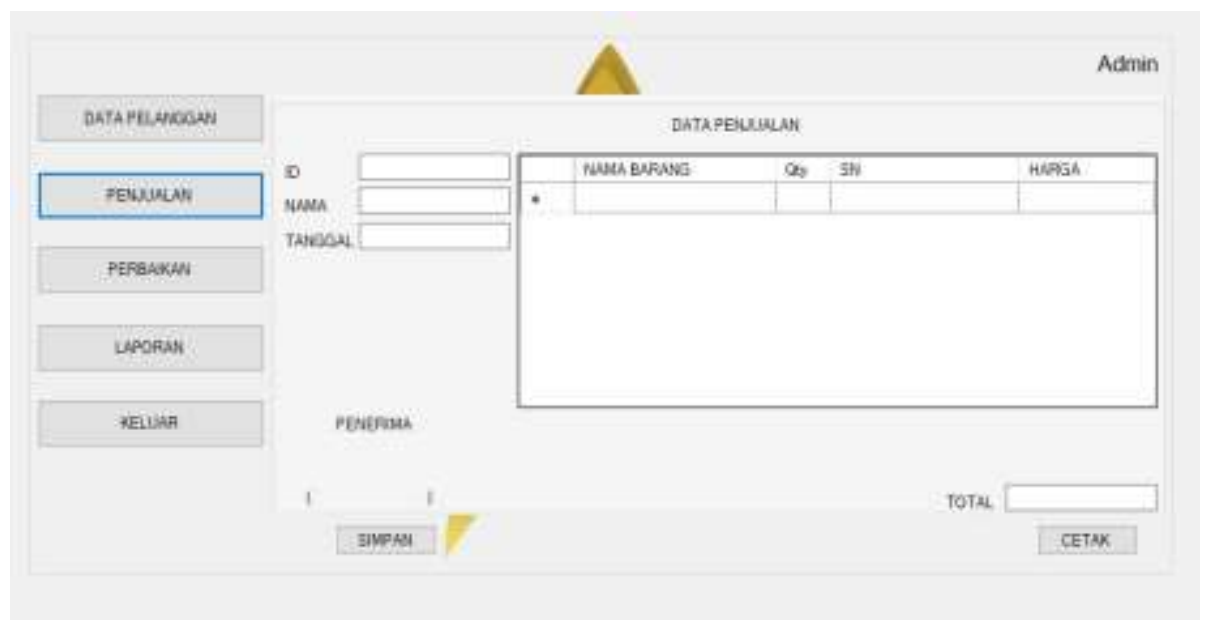

Gambar 5: Tampilan Halaman Admin

c) Halaman Kepala Toko

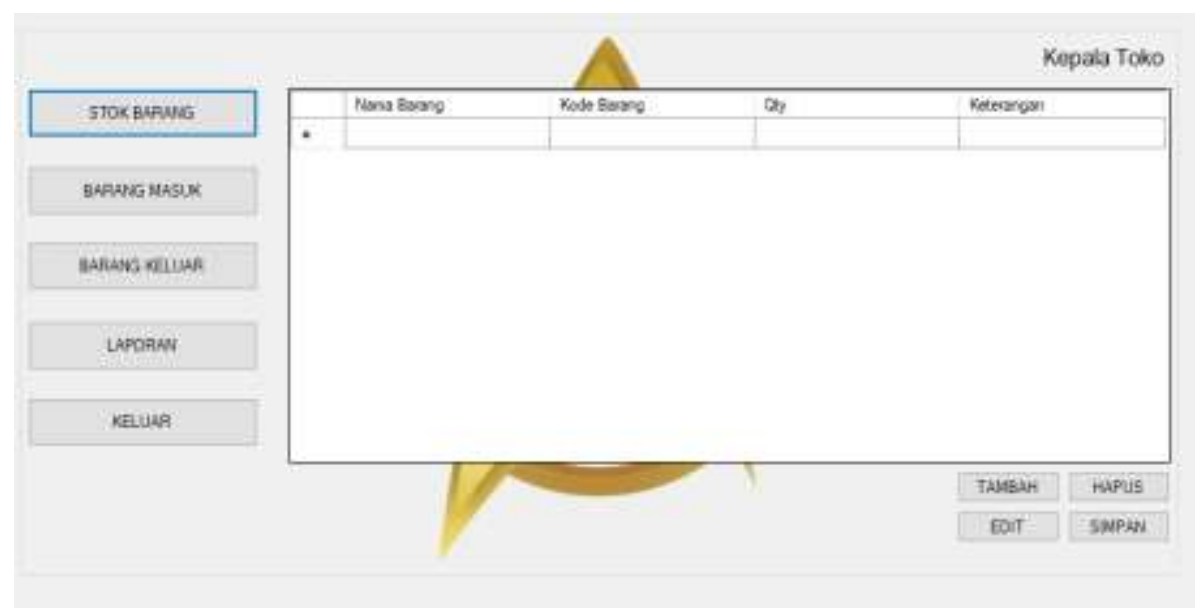

Gambar 6: Tampilan Halaman Kepala Toko

d) Halaman Pimpinan

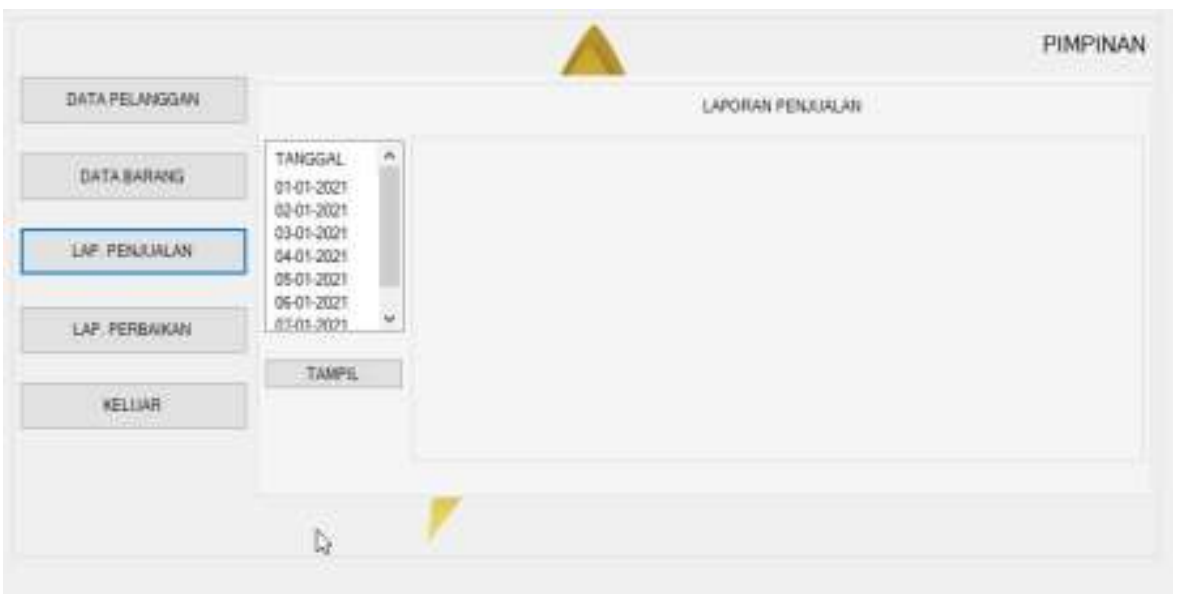

Gambar 7: Tampilan Halaman Pimpinan 


\section{KESIMPULAN}

Berdasarkan hasil penelitian maka didapat kesimpulan berupa, diharapkannya sistem yang dirancang dapat meminimalisir kesalahan seperti peng-input-an data pelanggan serta jenis service yang dilakukan karena seluruh data sudah tercatat di dalam sistem sehingga dapat mudahkan untuk diperiksa kembali. Data yang tersimpan juga menjadi lebih aman diakrenakan adanya sistem security data. Selain itu sistem ini juga dapat membuat pekerjaan karyawan pada TNG Computer menjadi lebih efektif dan efisien.

\section{SARAN}

Ada beberapa saran yang diusulkan yaitu :

1. Diharapkan penelitian ini dapat diimplementasikan dengan tepat oleh perusahaan

2. Dalam penelitan berikutnya perlu adanya pengembangan lebih lanjut agar sistem menjadi lebih kompleks lagi sesuai kebutuhan perusahaan

3. Perlu adanya back-up data untuk menghindari hilangnya data penting ketika terjadi error.

\section{UCAPAN TERIMAKASIH}

Penulis mengucakan terimakasih kepada Universitas Potensi Utama yang telah membantu dalam penyusunan penelitian ini. Selain itu juga kepada divisi LPPM Universitas Utama atas arahan dalam penyusunan paper sehingga menjadi penelitian yang baik.

\section{DAFTAR PUSTAKA}

[1] Astuti, Puspita Dwi (2017), "Sistem Informasi Penjualan Obat Pada Apotek Jati Farma Arjosari." Journal Speed - Sentra Penelitian Engineering dan Edukasi, Vol 3, No. 4, 34-39.

[2] Handayani, Sutri (2018), "Perancangan Sistem Informasi Penjualan Berbasis E-Commerce Studi Kasus Toko Kun Jakarta.” ILKOM Jurnal Ilmiah, Vol. 10, No. 2, 182-189.

[3] Irawan, A., Risa, M., Muttaqien, M. A., \& Shinnay, A. E. (2017). Perancangan Sistem Informasi Penjualan Pakaian Pada CV Nonninth Inc Berbasis Online. Jurnal Positif, 3(2), 74-82.

[4] Pebrianto, A., Abdillah, R., \& Valentino, V. H. (2020). Perancangan Sistem Informasi Penjualan Donat pada PT King Alianz Donuts. Jurnal Riset dan Aplikasi Mahasiswa Informatika (JRAMI), 1(03).

[5] Ananditya, A., Sriyono, S., \& Yanti, S. (2020). Perancangan Sistem Informasi Penjualan Voucher Game Online Berbasis Desktop pada Aren. Net di Depok. Jurnal Riset dan Aplikasi Mahasiswa Informatika (JRAMI), 1(01).

[6] Purnama, B. E. (2020). Perancangan Sistem Informasi Penjualan Pada Pt. Tugu Andalan Mandiri. IJNS-Indonesian Journal on Networking and Security, 9(4).

[7] Saputro, D. A. (2020). Perancangan Sistem Informasi Penjualan Ban Truk. IMTechno: Journal of Industrial Management and Technology, 1(1), 66-73.

[8] Simamora, H. I. T. (2020). Perancangan Sistem Informasi Penjualan Cv Mitra Tani Menggunakan Metode Prototype. JURTEKSI (Jurnal Teknologi dan Sistem Informasi), 6(2), 173-178. Sutanta, E. (2004). Sistem Basis Data. Yogyakarta: Graha Ilmu.

[9] Sidik, A., Sutarman, S., \& Marlenih, M. (2017). Perancangan Sistem Informasi Penjualan Perumahan Citra Raya. Jurnal Sisfotek Global, 7(1). 
[10] Aediyansyah, A. (2018). Perancangan Sistem Informasi Penjualan Daur Ulang Botol Bekas (Pet) Berbasis Web. Jurnal Riset Informatika, 1(1), 11-16.

[11] Chamid, A. A. (2016). Penerapan Metode Topsis Untuk Menentukan Prioritas Kondisi Rumah. Simetris: Jurnal Teknik Mesin, Elektro dan Ilmu Komputer, 7(2), 537-544.

[12] Sukamto, R. A., \& Shalahuddin, M. (2013). Rekayasa perangkat lunak terstruktur dan berorientasi objek. Bandung: Informatika, 3 .

[13] Sutanta, E. (2004). Sistem Basis Data. Yogyakarta: Graha Ilmu.

[14] Nugroho, E. (2008). Sistem Informasi Manajemen. Jakarta: Gramedia.

[15] Abdul, K. (2003). Pengenalan Sistem Informasi. Penerbit Andi, Yogyakarta.

[16] Arifah, D. (2013). Analisa dan Perancangan Sistem Pendukung Keputusan Pemilihan Kendaraan Menggunakan Metode TOPSIS. Jurnal Teknologi Informasi, 5(1), 41-42.

[17] Burch, John dan Gary Grudnitski. 1986. Information Systems Theory and. Practice. New York: John Wiley and Sons.

[18] Moekijat. 2011. Sistem Informasi Manajemen \& Definisi Data. Bandung: Remaja Roskadarya.

[19] Nore, V. N. (2013). Perancangan Sistem Informasi Penjualan Dan Pemesanan Produk Berbasis Web (Studi Kasus Di Cv. Richness Development Bandung).

[20] Corder, A. (1988). Teknik Manajemen Pemeliharaan. Edisi ke 2. 